\title{
Phytoplankton pigments in relation to carbon content in phytoplankton communities
}

\author{
Louise Schlüter*, Harry Havskum \\ The International Agency for ${ }^{14} \mathrm{C}$ Determination, VKI, Institute for the Water Environment, Agern Alle 11, \\ DK-2970 Horsholm, Denmark
}

\begin{abstract}
Measurements of natural marine phytoplankton communities were carried out in a mesocosm experiment by means of pigment analysis by HPLC to identify phytoplankton composition, and using microscopic identification of species and measurement of cell volume to estimate the carbon content of the phytoplankton groups. The enclosures were manipulated with additions of nutrients and mussels and reduction of light to induce changes in the phytoplankton communities. The trophic status of the individual enclosures was illustrated by $F_{p}$ ratios defined as the diagnostic pigments for diatoms and dinoflagellates divided by the total concentration of all diagnostic pigments. The $F_{p}$ ratios were significantly correlated to $F_{c}$ ratios, defined as the carbon content of dinoflagellates and diatoms divided by total phytoplankton carbon, suggesting that the phytoplankton diagnostic pigments can be used as both a qualitative and quantitative indicator of the respective phytoplankton groups.
\end{abstract}

KEY WORDS: Phytoplankton pigments HPLC $F_{\mathrm{p}}$ ratios $F_{\mathrm{c}}$ ratios $\cdot$ Chlorophyll a Carotenoids

\section{INTRODUCTION}

Phytoplankton pigments have contributed to the description of phylogeny and taxonomy of algal classes because the distribution of accessory pigments in the algal groups is quite unique (Weber \& Wettern 1980, Rowan 1989), and the pigments can be used diagnostically to identify the presence of individual phytoplankton groups in natural samples. In the last decade, pigment analyses carried out by high performance liquid chromatography (HPLC) have been increasingly used in qualitative investigations of phytoplankton group composition (e.g. Gieskes \& Kraay 1983, 1986, Klein \& Sournia 1987, Bidigare et al. 1990, Althuis et al. 1994) as an alternative to traditional microscopic analysis of phytoplankton. New HPLC techniques have improved separation and quantification of the phytoplankton pigments (e.g Mantoura \& Llewellyn 1983, Wright et al. 1991). The analysis by HPLC is rapid, very sensitive, and objective compared to microscopic enumerations, which are time-consuming and require taxonomic skill. Furthermore, particularly pico- and nano-sized

-E-mail: lsc@vki.dk algae require separate preparation techniques for identification, i.e. epifluorescence microscopy or electron microscopy. The taxonomic differentiation of these algae, at least to class level, can be aided by detecting their diagnostic pigments by HPLC (Hooks et al. 1988)

Quantitative investigations of the correlation and conformity between pigment analyses and microscopic analyses of phytoplankton group composition in natural samples are still few (Wilhelm et al. 1991, Tester et al. 1995). This lack of information is probably due to difficulties in obtaining precise microscopic estimations of phytoplankton cell density, volume, and carbon content and to the lack of established factors for converting the concentration of the diagnostic pigments to phytoplankton group abundance. A number of aberrations, however, are also associated with the general use of diagnostic pigments as tracers of specific algal groups. For example, prasinoxanthin occurs only in prasinophytes, but not all prasinophytes contain prasinoxanthin (Egeland et al. 1995). Some prymnesiophytes do not contain the diagnostic pigment $19^{\prime}$ hexanoyloxyfucoxanthin (Jeffrey \& Wright 1994), and some dinoflagellates contain 19'-hexanoyloxyfucoxan- 
thin instead of the marker pigment peridinin (Tangen $\&$ Björnland 1981). Further investigations on the correlations between pigment analyses and microscopic analyses are needed to evaluate the influence and extent of inconsistencies and to determine whether the pigment diagnosis only indicates qualitative aspects or includes quantitative patterns as well.

Recently, a pigment ratio $\left(F_{\mathrm{p}}\right)$ has been suggested as an indicator of the trophic status of a marine ecosystem (Claustre 1994). It is calculated as the integrated concentration of diagnostic pigments for diatoms and dinoflagellates (fucoxanthin and peridinin, respectively), divided by the integrated concentration of all diagnostic pigments (Claustre 1994). The ratio correlated well with chlorophyll a owing to the prevalence of diatoms and dinoflagellates in areas with new production according to the definition of Eppley \& Peterson (1979) (Claustre 1994). In this study, we tested the hypothesis that if there is correlation between the concentrations of the diagnostic pigments and the carbon content of the phytoplankton groups, then the $F_{p}$ ratios will be correlated to carbon ratios $\left(F_{c}\right)$, calculated as the carbon content of dinoflagellates and diatoms to all phytoplankton carbon. We chose a mesocosm approach to examine the time resolution of the diagnostic pigments and $F_{\mathrm{p}}$ and $F_{\mathrm{c}}$ ratios in natural phytoplankton communities exposed to changes in the nutrient, grazing, and light regimes.

\section{MATERIALS AND METHODS}

Mesocosm experiments were carried out in Knebel Vig, Denmark $\left(56^{\circ} 13^{\prime} \mathrm{N}, 10^{\circ} 27^{\prime} \mathrm{E}\right)$ from 26 June to 8 July 1994, and in Hylsfjord, Norway $\left(59^{\circ} 30^{\prime} \mathrm{N}\right.$. $6^{\circ} 30^{\prime} \mathrm{E}$ ) during the period 5 to 13 July 1995. In Knebel Vig, 10 large plastic enclosures, each with a volume of about 6000 l (depth: $4 \mathrm{~m}$, diameter-1.5 m) were filled. with water from the bay. The salinity was $24 \%$ r. The enclosures were attached to a pontoon bridge. The experimental set up is described in detail in Nybroe et al. (1992).

Two of the enclosures served as controls (C) Nitrate and phosphate were added to 2 enclosures (NP), and nitrate, phosphate and silicate were added to another 2 enclosures (NPSi). The nutrients were added daily from 26 to 29 June, to reach final concentrations of $14 \mu \mathrm{M} \mathrm{NO}_{3}{ }^{-}, 2 \mu \mathrm{M} \mathrm{PO}_{4}{ }^{3-}$ and $14 \mu \mathrm{M} \mathrm{SiO}_{4}{ }^{-}$. The nutrient concentrations were measured every day, and during the remaining part of the experimental period, nutrients were added to reach the concentrations above when the concentrations decreased to the detection level. Details on chemical and physical analyses are presented elsewhere $(\mathrm{H}$. Kaas, T. G. Nielsen \& J. N. Larsen unpubl.). Two enclosures (DL) were covered with green net filters to simulate the light quality and quantity that are prevalent in the decuer part of the water column in the coastal zone (Jerlov 1968). The solar radiance in the DL enclosures was reduced by $90 \%$. In 2 enclosures, 100 mussels (Mytilus edulis L.; $<3 \mathrm{~cm}$ in length) were placed in net bags in the middle of the enclosures (M). All enclosures were stirred with windmills.

Sampling was carried out in 3 depths every second day (with the exception of 28 June), and the 3 depths were pooled into 1 sample before sampling for microscopic enumerations and pigment analyses. Pigment analyses and phytoplankton cell enumerations were only carried out in one of the replicates, but spectrophotometrical analyses of total chlorophyll a and primary production were carried out in both enclosures and the replicates were very similar (i.e. generally $\pm 10 \%$ ) ( $\mathrm{H}$. Havskum, B. Riemann, K. Garde \& T K. Thingstad unpubl.).

In Hylsfjord, the mesocosm experiments consisted of 8 enclosures, each containing 16001 . The salinity was $7 \%$. The following nutrients were added daily to selected duplicate enclosures: nitrate $(N)$, nitrate and phosphate (NP), nitrate and glycine (NG), and nitrate, phosphate and glycine (NPG). The amount of nutrients added corresponded to final concentrations of $2 \mu \mathrm{M}$ $\mathrm{NO}_{3}{ }^{-}, 0.1 \mu \mathrm{MPO}_{4}{ }^{3-}$, and $4 \mu \mathrm{M}$ glycine. Glycine was added to examine possible carbon limitation and the results have been reported elsewhere (Havskum \& Hansen 1997). The $N$ enclosures acted as control enclosures, since the phytoplankton in Hylsfjord has been found to be phosphorus limited during the summer period (Aure \& Rey 1992, Thingstad et al. 1993).

The mesocosms were sampled as described for Knebel Vig. Samples for pigment analyses and microscopic identification were sampled every day. From 7 July on, samples for microscopic identification were only taken every second day. Further details on sampling and chemical and physical analyses are described in T. F. Thingstad, B. Riemann, D. Lefèvre, H. Kaas \& T G. Nielsen (unpubl.).

For microscopic determination of the phytoplankton, samples for determination of larger algae $1>20$ uml were fixed in Lugol's solution and enumerated using an inverted microscope. Samples for determination of pico and nano algae were fixed in glutaraldehyde, filtered onto black 0.2 and $0.8 \mu \mathrm{m}$ filters, and enumerated using an epifluorescence microscope. The phytoplankton cells were assigned to groups, and at least 100 cells were enumerated. For each group, at least 20 cells in each sample were measured. The cell volume was calculated by assigning simple geometric shapes to the organisms of which 1 or 2 dimensions were measured (HMSO 1990). The dimensions of naked flagellates were multiplied by a factor 1.1 to compensate for 
shrinkage due to fixation (Choi \& Stoecker 1989). Phytoplankton cell volume (for diatoms, the volume of the vacuole was subtracted from the cell volume) was converted to carbon biomass using conversion factors: $0.22 \mathrm{pg} \mathrm{C} \mu \mathrm{m}^{-3}$ and $0.25 \mathrm{pg} \mathrm{C} \mathrm{mm}^{-3}$ were used for prokaryotic and eukaryotic picoplankton, respectively (Søndergaard et al. 1991), 0.13 pg C $\mathrm{mm}^{-3}$ was used for thecate dinoflagellates, and $0.11 \mathrm{pg} C \mu \mathrm{m}^{-3}$ for all other phytoplankton cells (Mullin et al. 1966, BMEPCHC 1988)

For pigment analyses, 100 to $500 \mathrm{ml}$ water was filtered onto $25 \mathrm{~mm} \mathrm{GF/F} \mathrm{filters} \mathrm{which} \mathrm{were} \mathrm{frozen} \mathrm{and}$ stored in liquid nitrogen and analyzed within $3 \mathrm{mo}$. Prior to analysis, the filters were thawed, placed in $3 \mathrm{ml}$ $100 \%$ acetone, sonicated on ice, and stored cold for $24 \mathrm{~h}$. The samples were refiltered and injected into a Shimadzu LC-10A HPLC system according to the method described by Wright et al, (1991), with the following modifications: solvent $\mathrm{A}, 80: 20$ methanol:0.5 M ammonium acetate; solvent $B, 87.5: 12.5$ acetonitrile: water; solvent $\mathrm{C}$, ethyl acetate. The linear gradient was $0 \mathrm{~min}, 100 \% \mathrm{~A} ; 2 \mathrm{~min}, 100 \% \mathrm{~B} ; 2.6 \mathrm{~min}, 90 \% \mathrm{~B} / 10 \% \mathrm{C}_{\text {; }}$ $13.6 \mathrm{~min}, 65 \% \mathrm{~B} / 35 \% \mathrm{C} ; 20 \mathrm{~min}, 31 \% \mathrm{~B} / 69 \% \mathrm{C} ; 28 \mathrm{~min}$, $100 \% \mathrm{~B}_{;} 31 \mathrm{~min}, 100 \% \mathrm{~A}$; flow rate $1 \mathrm{ml} \mathrm{min} \mathrm{m}^{-1}$. The HPLC system was calibrated with pigment standards, kindly provided by R. R. Bidigare, University of Hawaii, and with pigment standards from The International Agency for ${ }^{14} \mathrm{C}$ Determination, Hørsholm, Denmark. Peak identities were routinely confirmed by online diode array.

The $F_{\mathrm{p}}$ ratios were calculated as described by Claustre (1994), although modified slightly, since the water column subsamples were integrated before analysis into one sample, as described previously (in Knebel Vig, the integrated samples represented the entire water column, while in Hylsfjord, the enclosures only reached a depth of $2 \mathrm{~m}$ ):

$F_{\mathrm{p}}=$ (fucoxanthin + peridinin $) /($ fucoxanthin + peridinin $+19^{\prime}$-hexanoyloxyfucoxanthin $+19^{\prime}$-butanoyloxyfucoxanthin + zeaxanthin + chlorophyll $b+$ alloxanthin)

The $F_{c}$ ratios were calculated as:

$F_{c}=$ (the carbon content in diatoms + the carbon content in dinoflagellates)/(the carbon content in all phytoplankton groups)

\section{RESULTS}

The manipulations in the enclosures in Knebel Vig resulted in changes in the phytoplankton pigment composition of the plankton communities (only diagnostic pigments will be treated). In the control enclo- sure, chlorophyll a (chl a), measured by HPLC, varied between 1.5 and $4.5 \mu \mathrm{g} \mathrm{l^{-1 }}$, fucoxanthin constituted around half of the accessory pigments, while zeaxanthin, chlorophyll $b(\mathrm{chl} b$ ), alloxanthin, 19'-hexanoyloxyfucoxanthin (19'-hex), and peridinin were present in varying amounts (Fig. 1). The pigment 19'-butanoyloxyfucoxanthin (19'-but) was detected in the middle of the experimental period and only in the control enclosure (Fig. 1). In the NPSi enclosure, chl a increased to $35 \mu \mathrm{g} \mathrm{l}^{-1}$ on 2 July closely followed by an increase in accessory pigments (Fig. 1). Fucoxanthin constituted more than $80 \%$ of the accessory pigments on 2 July with a decreasing tendency in the last part of the experimental period (Fig. 1). In the NP enclosure, chl a increased to almost $20 \mu \mathrm{g} \mathrm{l^{-1 }}$ in the middle of the experimental period, fucoxanthin constituted around $30 \%$ of the pigments, and peridinin became more concentrated in this enclosure compared to the control (Fig. 1). In the DL enclosure, chl a decreased, after a minor increase, to concentrations of 0.25 to $0.5 \mu \mathrm{g} \mathrm{l}^{-1}$, which was even lower than in the control at the end of the experimental period (Fig. 1). There was a substantial change in the phytoplankton pigment composition, including prevalence of fucoxanthin in the beginning, peridinin on 2 July, alloxanthin and chl bon 4 July, and finally, fucoxanthin again on 8 July (Fig. 1). In the M enclosure, chl a ranged between 0.9 and $2.6 \mu \mathrm{gl}^{-1}$, and the pigment composition changed from a prevalence of peridinin and fucoxanthin to prevalence of alloxanthin, zeaxanthin and chl $b$ (Fig. 1).

In Hylsfjord, the phytoplankton pigment composition was also influenced by the manipulations: chl a increased in the $\mathrm{N}$ and $\mathrm{NG}$ enclosures from $2 \mathrm{\mu g} \mathrm{l}^{-1}$ to respectively 5.5 and $8 \mu \mathrm{g} \mathrm{l}^{-1}$ in the middle of the experimental period, then decreased to concentrations around 3 to $4 \mu \mathrm{g} \mathrm{l}^{-1}$ (Fig. 2). The presence of phosphorus in the NP and NPG enclosures caused an increase in chl a to $12 \mu \mathrm{g} \mathrm{l}^{-1}$ on 10-11 July (Fig. 2). In all Hylsfjord enclosures, fucoxanthin and peridinin dominated the phytoplankton pigments (Fig. 2). Beside these 2 pigments, alloxanthin, zeaxanthin, and chl $b$ (of the diagnostic pigments) were detected. In the enclosures with added $P$, peridinin and fucoxanthin became even more prevalent, and the contribution of chl $b$ was reduced compared to the $N$ and $N G$ enclosures, while the level of zeaxanthin and alloxanthin was more or less similar to levels in N and NG (Fig. 2). The glycine addition did not have any distinctive effect on the phytoplankton pigments.

\section{The $F_{\mathrm{p}}$ and $F_{\mathrm{c}}$ ratios}

In Knebel Vig, the initial $F_{p}$ ratios ranged between 0.45 and 0.65 (Fig. 3a). Additions of NP did not 

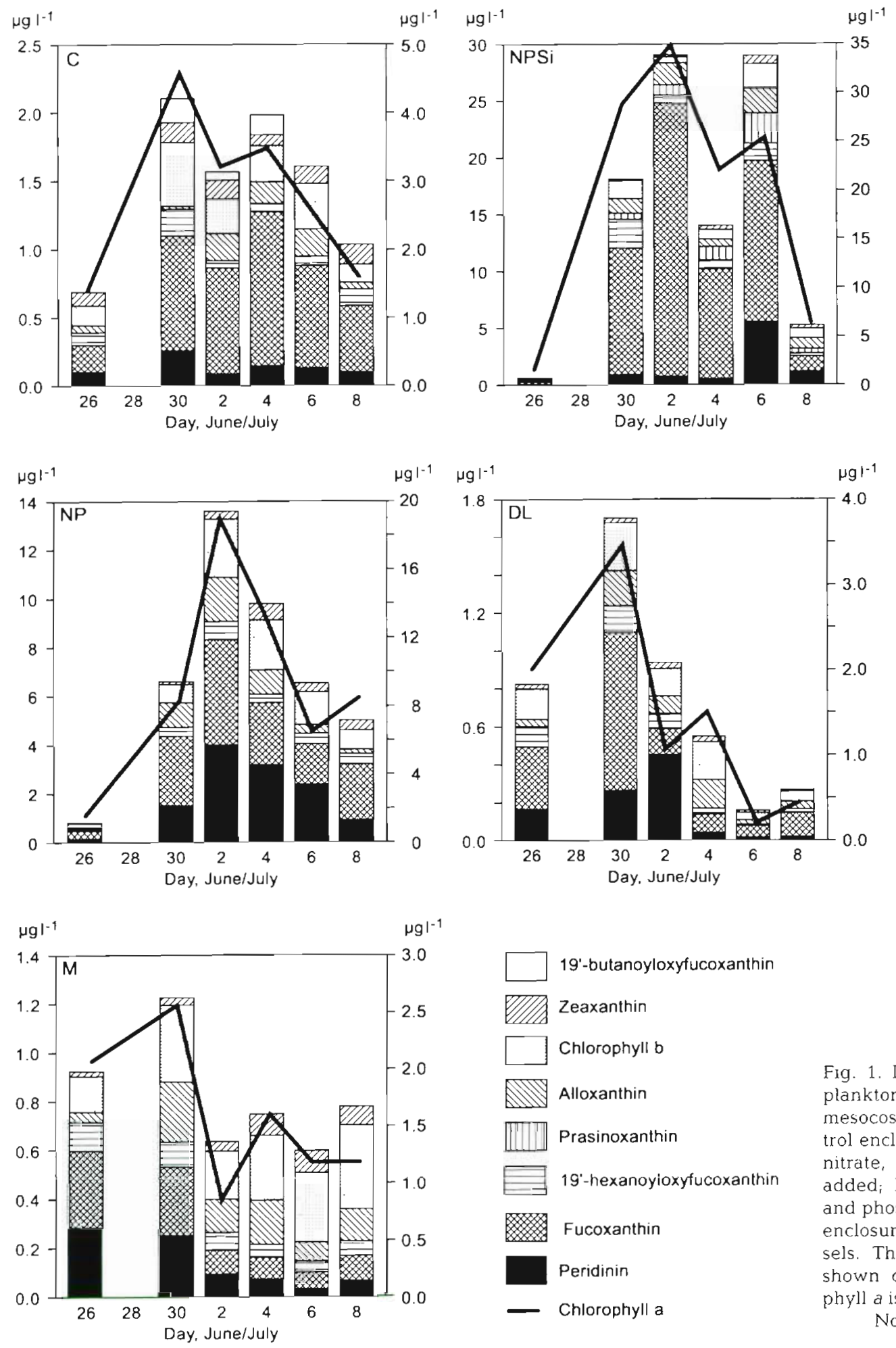

$\mu \mathrm{g}^{-1}$

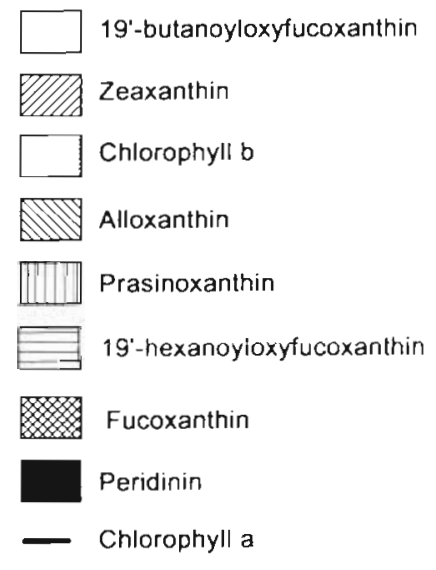

Fig. 1. Development in the phytoplankton pigments in Knebel Vig mesocosms, June/July 1994. C: control enclosure; NPSi: enclosure with nitrate, phosphate and silicate added; NP: enclosure with nitrate and phosphate added; DL: dim light enclosure; $\mathrm{M}$ : enclosure with mussels. The diagnostic pigments are shown on the left $y$-axes, chlorophyll $a$ is shown on the right $y$-axes. Note the different scales

change the $F_{\mathrm{p}}$ ratios, which remained relatively constant throughout the experimental period, and the ratios were also rather constant in DL except for 4 July, where the ratio dropped to 0.25 (Fig. 3a) In the NPSi enclosure, however, the ratio increased to almost 0.9 on 2 July, after which the ratio decreased again (Fig $3 a$ ). In the $M$ enclosure, the $F_{p}$ ratio decreased throughout the experimental period and reached the lowest measured value, at 0.2 , on 6 July (Fig 3a) 

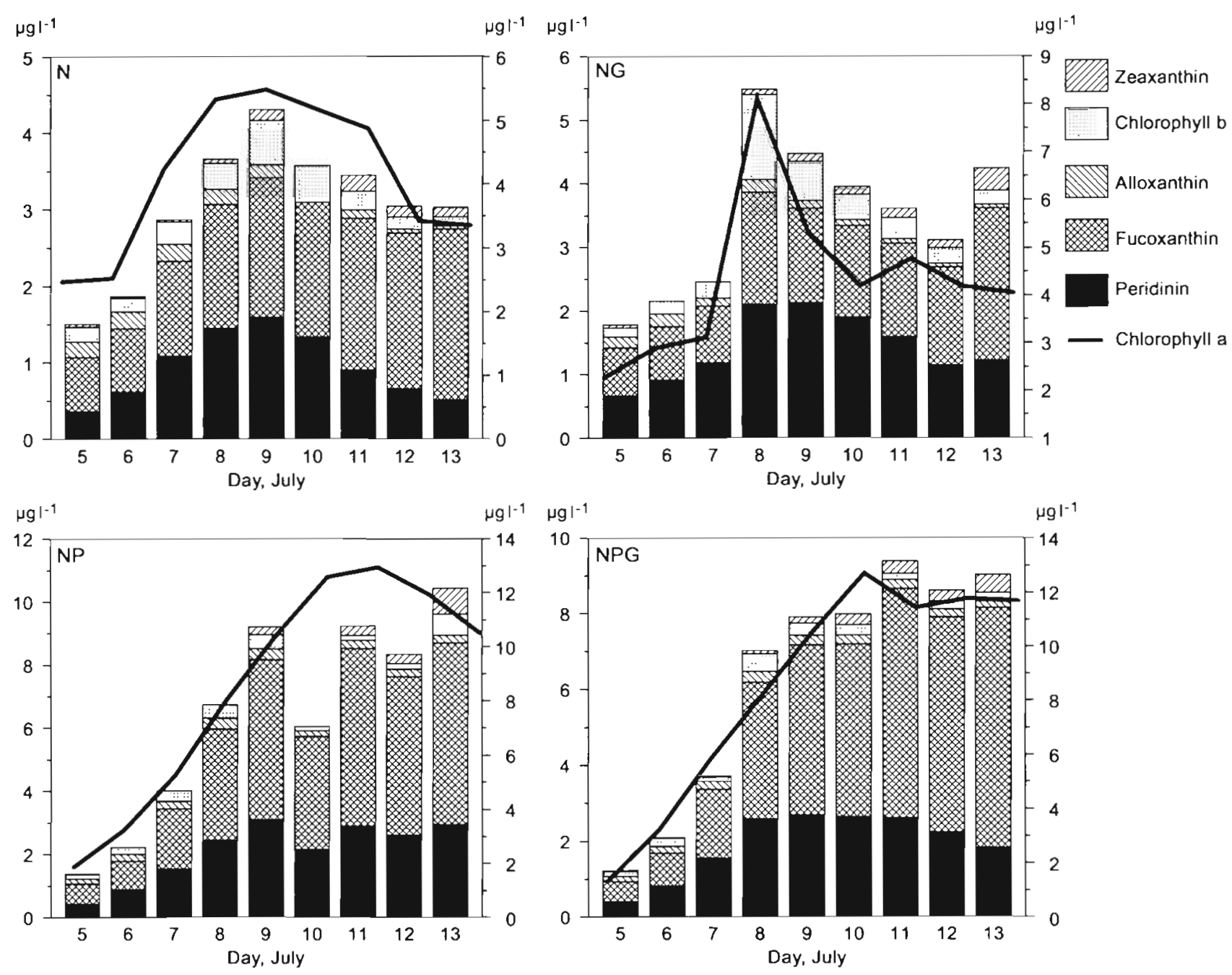

Fig. 2. Development in the phytoplankton pigments in Hylsfjord mesocosms, July 1995. N: enclosure with nitrate added; NG: enclosure with nitrate and glycine added; NP: enclosure with nitrate and phosphate added: NPG: enclosure with nitrate, phosphate and glycine added. The diagnostic pigments are shown on the first $y$-axes, chlorophyll $a$ is shown on the second $y$-axes. Note the different scales

The $F_{p}$ ratios in Hylsfjord ranged between 0.7 and 0.95 , and tended to increase in all enclosures during the experimental period (Fig. $3 \mathrm{~b}$ ). The $F_{\mathrm{p}}$ ratios in the NP and NPG enclosures were generally slightly higher than those in the N and NG enclosures (Fig. 3b).

The microscopic analyses confirmed the presence of phytoplankton groups which corresponded to the diagnostic pigments found in this study: dinoflagellates (peridinin), diatoms (fucoxanthin), prymnesiophytes (19'-hex), cryptophytes (alloxanthin), cyanobacteria (zeaxanthin), chlorophytes, euglenophytes, prasinophytes (chl b) and prasinophytes (prasinoxanthin). Furthermore, the following were identified by microscopic analysis of Knebel Vig samples: chrysophytes, dictyochophytes, pedinellophytes, sarcinochrysidophytes (all groups contain fucoxanthin /dictyochophytes and pedinellophytes were originally in- cluded in the class Chrysophyceae sensu Christensen (1962)], and eustigmatophytes (contain vaucheriaxanthin-like pigment (Karlson et al. 1996), which was not detected). 19'-but was formerly thought to be associated with chrysophytes, but after description of a new algal class, pelagophytes, $19^{\prime}$-but is now considered as the diagnostic pigment for this algae class (Andersen et al. 1993, 1996).

The $F_{\mathrm{c}}$ ratios were calculated from the carbon content determined from microscopic analysis, and all phytoplankton groups which were detected in Knebel Vig and Hylsfjord were included. The plot of $F_{\mathrm{c}}$ ratios against $F_{\mathrm{p}}$ ratios was divided in 2 groups: a Knebel Vig group, where the $F_{\mathrm{p}}$ ratios generally were below 0.70 and a Hylsfjord group, including a few Knebel Vig data points, where the $F_{\mathrm{p}}$ ratios were above 0.70 (Fig. 4). There was statistical significant correlation 

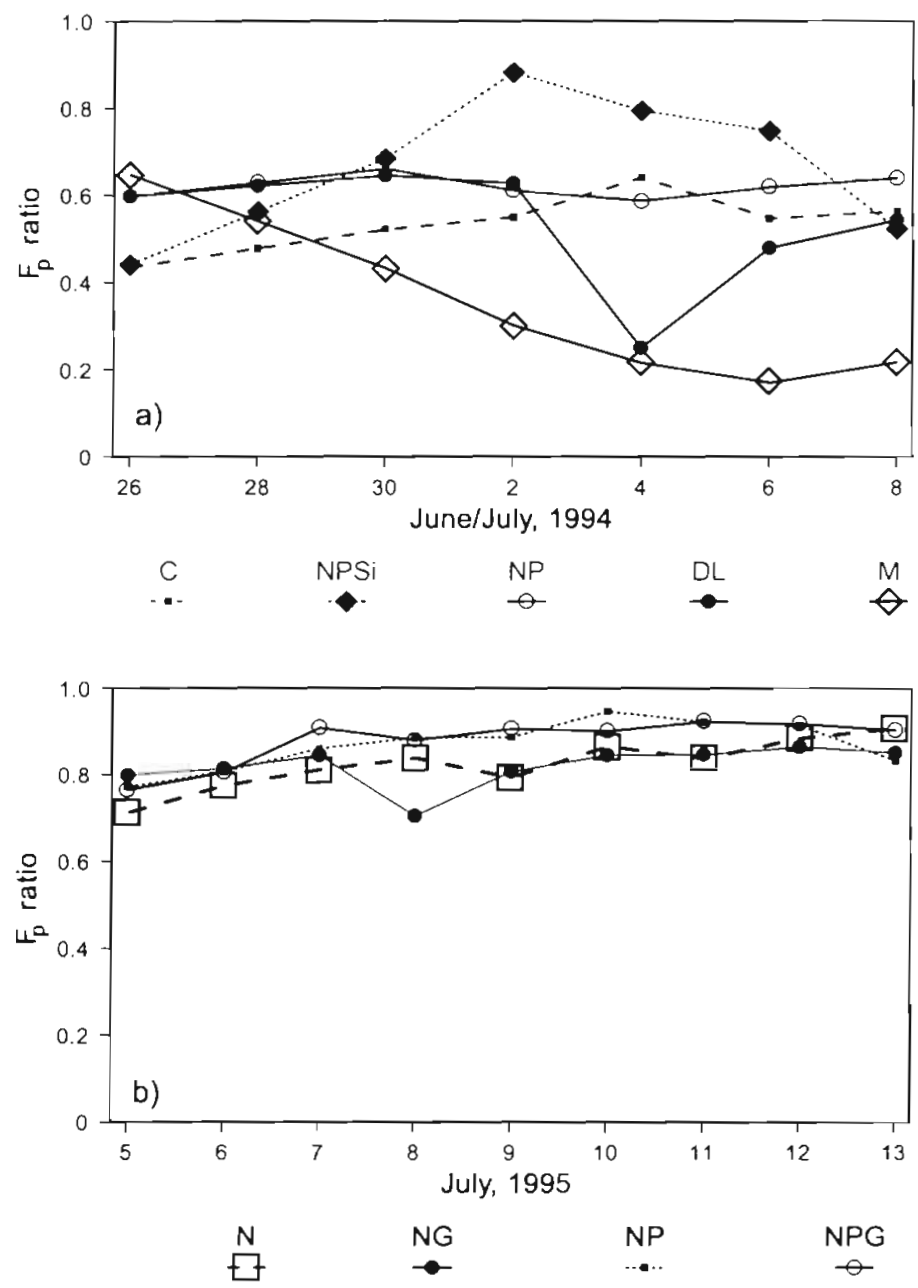

Fig. 3. Development in $F_{1}$ ratios in (a) Knebel Vig enclosures, June/July 1994 and in (b) Hylsfjord enclosures, July 1995. Enclosures as in Figs. 1 \& 2

between the $F_{c}$ ratios and the $F_{\mathrm{p}}$ ratios $\left(\mathrm{r}_{\mathrm{s}}=0.83, \mathrm{p} \ll\right.$ 0.001, Spearman's coefficient of variation). The $F_{p}$ ratios were generally higher than the $F_{c}$ ratios, and the Hylsfjord data set was closer to the ideal line $x=y$ than the Knebel Vig data set (Fig. 4).

All diagnostic pigments from the experiments in Knebel Vig and Hylsfjord were significantly correlated to chl a (Fig. 5). Fucoxanthin, alloxanthin and 19'-hex were tightly coupled to chl $a$, while the correlation of peridinin, and especially chl $b$ and zeaxanthin to chl $a$ was less obvious (Fig. 5). Furthermore, chl a was significantly correlated to total phytoplankton carbon $(y=$ $24.3 x+29.3 ; r^{2}=0.75, p \ll 0.05 ;$ Fig. 6). The enclosures with low phytoplankton content in Knebel Vig (C, $M$, and DL) were generally situated below the regression line in Fig. 6, indicating that the carbon/chl a relationships were lower for these data set than the rest of the Knebel Vig and Hylsfjord data set.

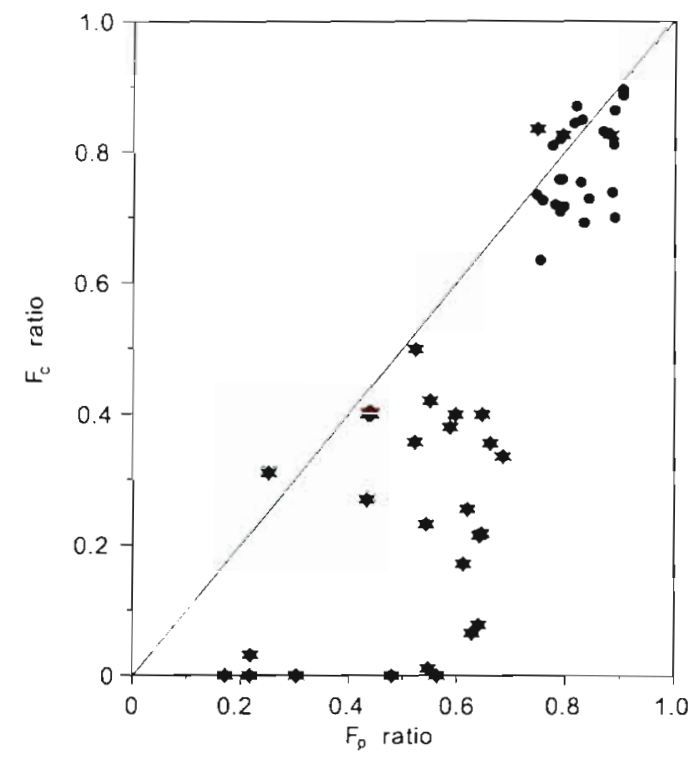

Fig. 4. Relationship between $F_{p}$ ratios and $F_{c}$ ratios (data on carbon content from Havskum et al. unpubl.), $r_{s}=0.83, p \ll 0.001$. ( ) Data from Hylsfjord enclosures; *) data from Knebel Vig enclosures

\section{DISCUSSION}

The manipulations of the environmental conditions in the enclosures induced marked changes in the phytoplankton pigment concentrations and composition compared to the control enclosures [C in Knebel Vig and N (NG) in Hylsfjord; Figs. 1 \& 2]. Especially in Knebel Vig, chl a ranged from 0.25 to $35 \mu \mathrm{g} \mathrm{chl} \mathrm{a} \mathrm{l}^{-1}$ (Fig. 1). a more than 100 -fold biomass variation. In the study period, a large number of different phytoplankton communities had developed which permitted a comprehensive analysis of the relationship between the occurrence of diagnostic pigments and the presence of specific algal groups.

Two important messages came out of the exercise. First, there was a promising significant correlation overall between the $F_{p}$ and the $F_{c}$ ratios (Fig. 4). Second, a significant correlation was found between chl $a$ and the individual diagnostic pigments (Fig. 5) and between phytoplankton carbon and chl a (Fig. 6). A comparison between the pigments and the microscopic observations is constrained, however, by the fact the pigment content of the phytoplankton cells changes, e.g. when the phytoplankton cells photoacclimate (reviewed by Falkowski \& LaRoche 1991). Some of the data set in this study (C, M and DL enclosures in Knebel Vig) were deviating slightly from the rest by having lower carbon/ chl a relationships (Fig 6). On the other hand, micro- 

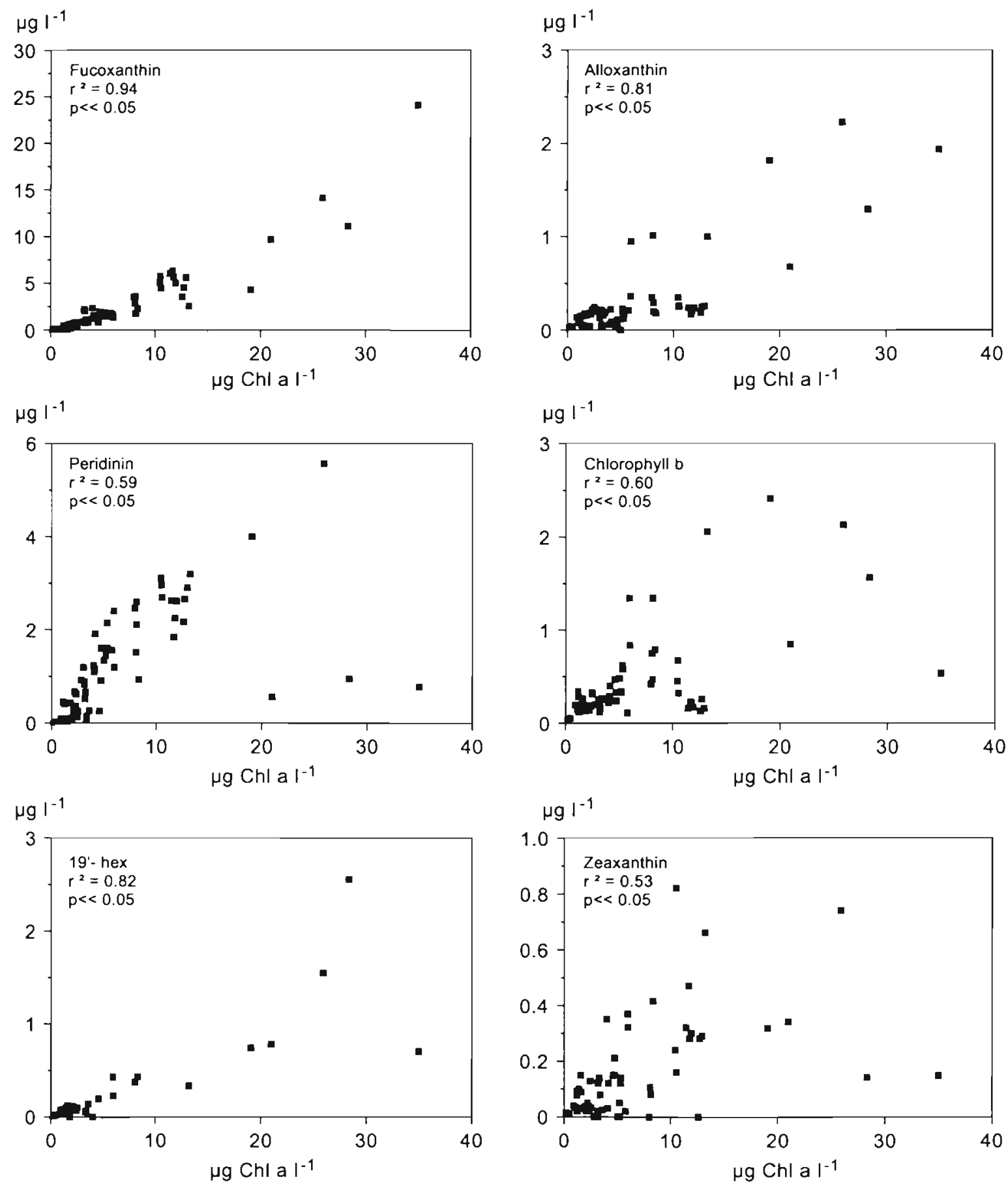

$\mu g 1^{-1}$

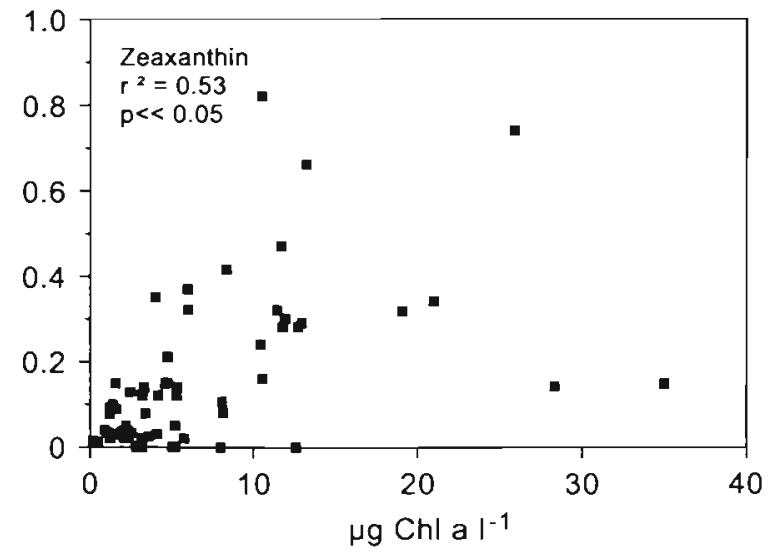

Fig. 5. Relationship between the diagnostic pigments and chlorophyll a. Data from Knebel Vig and Hylsfjord enclosures

scopic analysis gives a group-specific picture including details that cannot be attained by other techniques. While the comparison is not optimal, there is presently no better way to evaluate the pigment signals.

The deviations from the ideal line, $x=y$, between $F_{\mathrm{p}}$ and $F_{\mathrm{c}}$ in Fig. 4 are due to several factors. Fucoxanthin is a marker pigment for diatoms, but many members of the division Chromophyta are reported to contain fucoxanthin, including the chrysophytes, pedinellophytes, dictyochophytes, sarcinochrysidophytes mentioned above, as well as prymnesiophytes (e.g. Rowan 1989). Fucoxanthin deriving from algae groups other than diatoms has increased the $F_{\mathrm{p}}$ ratio in relation to the $F_{\mathrm{c}}$ ratio. Furthermore, while peridinin is a unique marker 


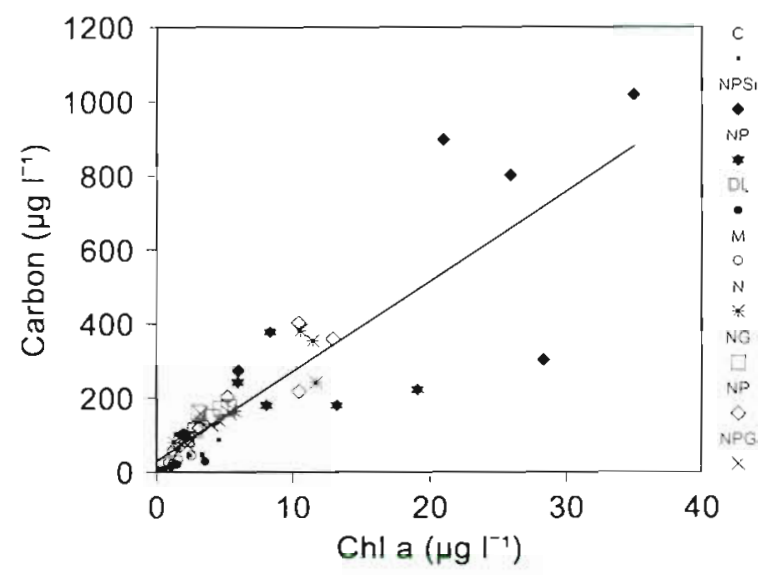

Fig. 6. Relationship between phytoplankton carbon and chlorophyll a $\left(y=24.3 x+29.3 ; r^{2}=0.75\right)$. Data from Knebel

Vig and Hylsfjord enclosures. Enclosures as in Figs. 1 \& 2

pigment for dinoflagellates, some dinoflagellates do not contain peridinin (Tangen \& Björnland 1981), but the $F_{\mathrm{p}}-F_{\mathrm{c}}$ relationship has probably not been seriously affected by the presence of non-peridinin-containing dinoflagellates.

While the precision in HPLC analyses is usually high [coefficient of variation, CV < 5\%; Latasa et al. (1996)], the microscopic enumerations typically have large standard deviations: Wilhelm et al. (1991) found standard deviations of between 15 and $50 \%$ on countings and estimations of the biovolume of the major algal groups. The reproducibility of the countings is of course related to the numbers of cells counted. The variation arises e.g. in connection with the seldom occurrence of large phytoplankton species in the counted subsamples. Since much larger quantities of water are filtered for sample analysis by HPLC (usually 50 to 100 times the amount used for microscopic estimations), this problem of variation is diminished when using HPLC for phytoplankton group detection. An example is the microscopic enumeration of phytoplankton in the control enclosures in Knebel Vig (data shown in Havskum et al. unpubl.., where the dinoflagellates disappeared on 8 July from the countings, while peridinin was still present in the pigment extract (Fig 1). The dinoflagellates were apparently not detected in the microscope, probably because of few large cells that did not appear in the small volume of the subsample counted. Such inconsistencies can have contributed to the lowered $F_{\mathrm{t}}$ ratios in relation to the $F_{\mathrm{p}}$ ratios seen in Fig. 4

Of minor importance for the $F_{\mathrm{p}}-F_{\mathrm{c}}$ relationship are inconsistencies within algal groups other than dinoflagellates and diatoms. For example, chl $b$ was detected in the pigment extract on 8 July in the control, but chlorophytes, prasinophytes, and euglenophytes, which all contain chl $b$, were not detected in the cell countings. This could indicate that prochlorophytes constituted a part of the pigmented picoplankton assigned to cyanobacteria or that prochlorophytes were simply not detected in the microscopic observations (no attempt was made to separate divinyl chl $a$ and $b$, the diagnostic pigments for prochlorophytes, from monovinyl chl a and $b$ with the HPLC method used in this study). Furthermore, in the control enclosure, 19'-but appeared in the middle of the experimental period (Fig 1), but pelagophytes were not detected in the cell counting. Either 19'-but originated from other 19'-but containing phytoplankton groups [e.g. dinoflagellates or prymnesiophytes (Liaaen-Jensen 1985. Wright \& Jeffrey 1987)], or pelagophytes were not identified.

Contrary to the Knebel Vig data set, the diagnostic pigments and the corresponding phytoplankton groups of the control and other Hylsfjord enclosures revealed $F_{\mathrm{p}}$ and $F_{\mathrm{c}}$ ratios, which were much closer to the ideal line $x=y$ in Fig. 4. The phytoplankton in Hylsfjord differed from the phytoplankton population in Knebel Vig, since almost no pigmented picoplankton $(<1 \%$ of the pigmented biomass) was present (Havskum \& Hansen 1997). Possible misidentification or uncounted pigmented picoplankton was thus unimportant

The $F_{\mathrm{p}}$ ratios were between 0.45 and 0.65 in the control in Knebel Vig and between 0.7 and 0.95 in the controls in Hylsfjord (Fig. 3), corresponding to mesotrophic and mesotrophic/eutrophic ecosystems respectively, which are characterized as transient and unsteady according to Claustre (1994). In such environments, the phytoplankton consists generally of opportunistic, large forms (Fogg 1991, Claustre 1994), such as diatoms and dinoflagellates. These groups responded to $\mathrm{P}$ addition in Hylsfjord, and in the NPSi enclosure in Knebel Vig, Si addition caused an enormous increase in diatoms (also confirmed by microscopic observations; Havskum et al. unpubl.). The development of the $F_{\mathrm{p}}$ ratios in the NPSi enclosure (Knebel Vig) as well as in the enclosures added $P$ in Hylsfjord coincided with the development of chl a (Figs. 1 \& 3). This is in accordance with the observations of Claustre (1994), who found that $F_{p}$ ratios were positively related to chl a. In the NP enclosure in Knebel Vig, however, the $F_{\mathrm{p}}$ ratios remained constant, whereas chl $a$ and the diagnostic pigments increased (although the pigment concentrations decreased after 2 July, the level was still several times higher than in the control). The nutrient addition apparently caused an increase in all phytoplankton groups, rather than only diatoms and dinoflagellates (Fig 1).

In the $M$ enclosure, the $F_{\mathrm{p}}$ ratios and the chl a decreased due to filtration by Mytilus edulis (Figs. 1 \& 3). In particular, the lowered $F_{\mathrm{p}}$ ratios and the decrease of peridinin and fucoxanthin (Fig. 1) indicated that 
dinoflagellates and diatoms were preferably taken up by the mussels. Periods with high pelagic heterotrophic grazing activity might also cause similar displacements in the phytoplankton composition, which explain some of the large variations in $F_{p}$ ratios observed by Claustre (1994) in mesotrophic areas $(0.15$ to 0.85$)$ and also found in this study.

Light deprivation also influenced the phytoplankton pigments (DL, Fig 1), although the $F_{p}$ ratio was affected only on 4 July (Fig 3). The increase in all phytoplankton pigments on 30 June, except zeaxanthin, which is considered as a photoprotective pigment (Bidigare et al. 1989, Demmig-Adams 1990), reflected an adaptation to the lowered light intensity in this enclosure, since the carbon content decreased during the whole experimental period (Havskum et al. unpubl.). The cellular increase in photosynthetic active pigments at the beginning of the experimental period could, however, not compensate for the severe reduction in light intensity. The photosynthetic pigments absorb poorly in green light (Johnsen et al. 1992, Schubert et al. 1995), which prevailed in this enclosure, and the low light intensity of a poor quality probably caused the observed extinction of the phytoplankton in the DL enclosure (Fig. 1).

Recently, a study of the composition of natural phytoplankton populations in oligotrophic waters determined with HPLC measurements showed general agreement with direct electron microscope taxonomic identifications of the relative composition of the phytoplankton groups (Andersen et al. 1996). In the present study, the correlation between $F_{\mathrm{p}}$ and $F_{\mathrm{c}}$ suggests that the relationship between the phytoplankton pigments and the phytoplankton group composition is not only of a qualitative character. Furthermore, the individual diagnostic pigments were positively correlated to the chl a concentrations, although some of the relationships, i.e. chl b, 19'-hex and zeaxanthin (which is a photoprotective pigment, and was not expected to vary in relation to chl a) were variable (Fig. 5). This is in accordance with Gieskes et al. (1988), who found general correlation between chl $a$ and the individual accessory pigments within areas divided by a cluster analysis in the Banda Sea. But when the trophic status of various oceanic provinces were considered, from oligotrophic to eutrophic areas, Claustre (1994) found that fucoxanthin and to a lesser extent peridinin were the only pigments which were correlated to chl a standing stocks.

Correlation between the individual diagnostic pigments and chl a is, nevertheless, a necessary assumption for carrying out multiple linear regression for calculating the contribution of each phytoplankton pigment to the total chl a. Multiple linear regression has been used to quantify the contribution of the indi- vidual phytoplankton groups of chl a (Gieskes et al 1988, Bustillos-Guzmán et al. 1995, Tester et al. 1995) in order to convert the concentrations of the diagnostic pigments to phytoplankton group biomass expressed as chl a. The many variables (up to 10 diagnostic pigments) enable a quite precise prediction of chl $a$. The variation of the pigment concentrations, however, does result in some unrealistic values, which necessitates constraining the constant values in the multiple regression (Barlow et al. 1993, BustillosGuzmán et al. 1995). Depending on the choice of suitable constant values, the result of the multiple linear regression can be highly variable. An alternative method for calculating the contribution of the diagnostic pigments of $\mathrm{chl} a$ is to use the ratios between the diagnostic pigments and chl a derived from laboratory experiments as seed values (Everitt et al. 1990 , Letelier et al. 1993). More experiments on the influence of the quality and quantity of light and trophic relationships, e.g. nutritional conditions, on the ratios between diagnostic pigments and chl a could probably provide different seed values for areas of different trophic states and different light climates. The division of chl a into different phytoplankton groups on the basis of the concentration of the diagnostic pigments is a more obvious method for quantifying the phytoplankton groups than converting concentrations of the diagnostic pigments to carbon content, since the carbon content of phytoplankton cells in relation to pigment content probably varies in a less apparent way than the diagnostic pigments in relation to chl a. The use of seed values can aid to determine the contribution of each phytoplankton group to total chl a

In conclusion, the significant correlations between $F_{p}$ and $F_{\text {s }}$ for the phytoplankton communities examined suggested that the diagnostic pigments could be used to obtain information on the occurrence of important algal groups and their quantitative contribution to the standing stock of pigmented microorganisms. Considering the methodological advantages (higher precision, faster, and cheaper) of the pigment approach over microscopic investigations, an intensified use of pigment techniques is justified both in general studies of production, flux, and fate of organic matter dynamics and in descriptions of the diversity of phytoplankton communities.

Acknowledgements. This study was supported by the Danish Environmental Research Programme, The International Agency for ${ }^{1+} \mathrm{C}$ Determination, VKI, a MAST Il contract (MAS2-CT92-0031-MEICE) and a MAST III contract (ELOISE, MAS3-CT96-0053-PHASE). We thank Bo Riemann for helpful suggestions, Caroline Cailliau and Morten Sondergaard for critically reading the manuscript, and Winnie Martinsen for technical assistance. 


\section{LITERATCRE CITED}

Althuis IJA, Gieskes WWC, Villenus L, Colijn F (1994) Interpretation of fluorometric chlorophyll registrations with algal pigment analysis along a ferry transect in the southern North Sea. Neth J Sea Res 33:37-46

Andersen RA, Bidigare RR, Keller MD, Latasa M (1996) A comparison of HPLC pigment signatures and electron miroscoplc observations for oligotrophic waters of the North Allantic and Pacific Oceans. Deep Sea Res 43: $517-537$

Andersen RA, Saunders GW, Paskind MP, Sexton JP (1993) Ultrastructure and $18 \mathrm{~S}$ rRNA gene sequence for Pelagomonas calceolata gen. et sp. nov. and the desciption of a new algal class, the Pelagophyceae classis nov. J Phycol 29:701-715

Aure J, Rey F (1992) Oceanographic conditions in the Sandsfjord System, Western Norway, after a bloom of the toxıc prymnesiophyte Prymnesium parvum Carter in August 1990. Sarsia 76:247-254

Barlow RG, Mantoura RFC, Gough MA, Pileman TW (1993) Pigment signatures of the phytoplankton composition in the northeastern Atlantic during the 1990 spring bloom. Deep Sea Res 411:459-477

Bidıgare RR, Marra J, Dickey TD, Iturraga R, Baker KS, Smith RC, Pak H (1990) Evidence for phytoplankton succession and chromatic adaption in the Sargasso Sea during spring 1985. Mar Ecol Prog Ser 60:113-122

Bidigare RR, Schofield O, Prézelin BB (1989) Influence of zeaxanthin on quantum yield of photosynthesis of Synechococcus clone WH7803 (DC2). Mar Ecol Prog Ser 56: $177-188$

BMEPC-HC: Baltic Marıne Environmental Protection Commision-Helsinki Commission (1988) Guidelines for the Baltic montoring programme for the third stage, Part D Biological determinands. Baltic Sea Environ Proc 27:1-161

Bustillos-Guzmán J, Claustre H, Marty JC (1995) Specific phytoplankton signatures and their relationship to hydrographic conditions in the coastal northwestern mediterranean sea. Mar Ecol Prog Ser 124:247-258

Choi JW. Stoecker DK (1989) Effects of fixation on cell volume of marine planktonic protozoa. Appl Environ Microbiol 55 $1761-1765$

Christensen T (1962) Botanik, Vol 2, Systematisk Botanik, No 2. Alger. Munksgaard, Kobenhavn (in Danish)

Claustre H (1994) The trophic status of various oceanic provinces as revealed by phytoplankton pigment signatures. Limnol Oceanogr 39:1207-1211

Demmig-Adams B (1990) Carotenolds and photoprotection in plants: a role for the xanthophyll znaxanthin. Biochim Biophys Acta 1020:1-24

Egeland ES, Eikrem W, Throndsen J, Wilhelm C, Zapata M, Liaaen-Jensen S (1995) Carotenoids from further prasinophytes. Biochem Syst Ecol 23:747-755

Eppley RW, Peterson BJ (1979) Particulate organic matter flux and planktonic new production in the deep ocean. Nature 282:677-680

Everitt DA, Wright SW, Volkman JK, Thomas DP, Lundstrom EJ (1990) Phytoplankton commurit compositions in the western equatorial Pacific determmed from chlorophyll and carotenoid pigment distributions. Deep Sea Res 37: 975-997

Falkowskı PG, LaRoche J (1991) Acclimation to spectral irradiance in algae. J Phycol 27:8-14

Fogg GE (1991) The phytoplanktonic ways of life. New Phytol 118:191-232

Gieskes WWC, Kraay GW (1983) Dominance of Cryptophy- ceae during the phytoplankton spring bloom in the central North Sea detected by HPLC analysis of pigments. Mar Biol 75:179-185

Gieskes WWC, Kraay GW (1986) Floristic and physiological differences between the shallow and the deep nanophytoplankton community in the euphotic zone of the open tropical Atlantic revealed by HPLC analysis of pigments. Mar Biol 91:567-576

Gieskes WWC, Kraay GW, Nontji A, Setiapermana D, Sutomo (1988) Monsoonal alternation of a mixed and a layered structure in the phytoplankton of the euphotic zone of the Banda Sea (Indonesia): a mathematıcal analysis of algal pigment fingerprints. Neth J Sea Res 22:123-137

Havskum, H. Hansen AS (1997) Importance of pigmented colourless nano-sized protists as grazers on nanoplankton in a phosphate-depleted Norwegian fjord and in enclosures. Aquat Microb Ecol 12:139-151

HMSO (Her Majesty's Stationery Office) (1990) The enumeration of algae, estimation of cell volume, and use in bioassays. Methods for the examination of waters and associated material. HMSO, London, $\mathrm{p}$ 1-44

Hooks CE, Bidigare RR, Keller MD, Guillard RRL (1988) Coccoid eukaryotic marne ultraplankters with four different HPLC pigment signatures. J Phycol 24:571-580

Jeffrey SW, Wright SW (1994) Photosynthetic pigments in the Haptophyta. In: Green JC, Leadbeater BSC (eds) The haptophyte algae. Clarendon Press, Oxford, p 111-132

Jerlov NG (1968) Optical oceanography. Elsevier Publishing Company, Amsterdam

Johnsen G, Sakshaug E, Vernet M (1992) Pigment composition, spectral characterization and photosynthetic parameters in Chrysochromulina polylepis. Mar Ecol Prog Ser 83 241-249

Karlson B, Potter D, Kuylenstierna M, Andersen RA (1996) Ultrastructure, pigment composition, and $18 \mathrm{~S}$ rRNA gene sequence for Nannochloropsis granulata sp. nov. (Monodopsidaceae, Eustigmatophyceae), a marine ultraplankter isolated from Skagerrak, northeast Atlantic Ocean. Phycologia 35:253-260

Klein B, Sournia A (1987) A daily study of the diatom spring bloom at Roscoff (France) in 1985. II. Phytoplankton pigment composition studied by HPLC analysis. Mar Ecol Prog Ser 37:265-275

Latasa M, Bidigare RR, Onsdrusek ME, Kennicut MC (1996) HPLC analysis of algal pigments: a comparison exercise among laboratories and recommendations for improved analytical performance. Mar Chem 51:315-324

Letelier RM, Bidigare RR, Hebel DV, Ondrusek M, Winn CD, Karl DM (1993) Temporal variabulsty of phytoplankton community structure based on pigment analysis. Limnol Oceanogr 38:1420-1437

Liaaen-Jensen S (1985) Carotenoids of lower plants - recent progress. Pure Appl Chem 57:649-658

Mantoura RFC. Llewellyn CA (1983) The rapid determination of algal chlorophyll and carotenoid pigments and their breakdown products in natural waters by reverse-phase high-performance liquid chromatography. Anal Chim Acta 151:297-314

Mullin MM, Sloan PR. Eppley PW (1966) Relationship between carbon content, cell volume, and area in phytoplankton. Limnol Oceanogr 11:307-311

Nybroe O, Christoffersen K, Riemann B (1992) Survival of Bacllus licheniformıs in seawater model ecosystems. Appl Environ Microbiol 58:252-259

Rowan KS (1989) Photosynthetic pigments of algae. Cambridge University Press, Cambridge

Schubert H, Forster RM. Sagert S (1995) In situ measurement 
of state transition in cyanobacterial blooms - kinetics and extent of the state change in relation to underwater light and vertical mixing. Mar Ecol Prog Ser 128:99-108

Søndergaard M, Jensen LM, Ertebjerg G (1991) Picoalgae in Danish coastal waters during summer stratification. Mar Ecol Prog Ser 79:139-149

Tangen K, Björnland T (1981) Observations on pigments and morphology of Gyrodinium aureolum Hulburt, a marine dinoflagellate containing 19 ' -hexanoyloxyfucoxanthin as the main carotenoid. J Plankton Res 3:389-401

Tester PA, Geesey ME, Chunzhi G, Pearl HW, Millie DF (1995) Evaluating phytoplankton dynamics in the Newport River estuary (North Carolina, USA) by HPLCderived pigment profiles. Mar Ecol Prog Ser 124:237-245

Thingstad TF. Skjoldal EF, Bohne RA (1993) Phosphorus cycling and algal-bacterial competition in Sandsfjord, western Norway. Mar Ecol Prog Ser 99:239-259

This article was submitted to the editor
Weber A, Wettern M (1980) Some remarks on the usefulness of algal carotenoids as chemotaxonomic markers. In Czygan FC (ed) Pigments in plants. Fisher, Stuttgart, p $104-116$

Wilhem C, Rudolph I, Renner W (1991) A quantitative method based on HPLC-aided pigment analysis to monitor structure and dynamics of the phytoplankton assemblages - a study from Lake Meerfelder Maar (Eifel, Germany). Arch Hydrobiol 123:21-35

Wright SW, Jeffrey SW (1987) Fucoxanthin pigment markers of marne phytoplankton analysed by HPLC and HPTLC. Mar Ecol Prog Ser 38:259-266

Wright SW, Jeffrey SW, Mantoura RFC, Llewellyn CA, Bjørnland T, Repeta D, Welschmeyer N (1991) Improved HPLC method for the analysis of chlorophylls and carotenoids from marine phytoplankton. Mar Ecol Prog Ser 77 183-196

Manuscript received: November 14, 1996

Revised version accepted: May 9, 1997 